\title{
CZYNNIKI SUKCESU ZARZĄDZANIA PROJEKTAMI USLUG IT
}

DOI: 10.33141/po.2020.08.04

\author{
Szymon Zaleski, Rafał Michalski
}

Przegląd Organizacji, Nr 8(967), 2020, s. 29-36

www.przegladorganizacji.pl

๑ Towarzystwo Naukowe Organizacji i Kierownictwa (TNOiK)

\section{Wprowadzenie}

W świecie szybkich i ciągłych zmian rozwój technologii informacyjnych (IT) ma olbrzymie znaczenie dla przedsiębiorstw praktycznie $\mathrm{z}$ wszystkich branż. W związku z tym, skuteczność rozwiązań w tym obszarze ma bezpośredni wpływ na konkurencyjność firm wdrażających takie systemy informatyczne. Poza tym jakość oraz terminowość projektowanych i wdrażanych pomysłów decyduje o możliwościach przetrwania i rozwoju przedsiębiorstw z branży IT. Niestety, pomimo bardzo dużych nakładów czasu, pieniędzy i zaangażowania w projekty, wciąż często nie kończą się one sukcesem. Z tego względu zainteresowanie badaniami w tym zakresie jest znaczne (Konieczna, 2019). Brak sukcesu wiąże się z opóźnieniami, licznymi modyfikacjami pierwotnych założeń, znaczącą zmianą zakresu działania systemu czy jego funkcjonalności lub ich przerwaniem i porzuceniem (Standish, 2015; Varajao i in., 2018). W dzisiejszych czasach coraz więcej dużych i złożonych organizacji przekształca swoje usługi IT, korzystając z wielu różnych technik i metod. Wśród nich coraz większą popularnością cieszą się podejścia, gdzie tradycyjne i zwinne (Szpitter, 2012) środowiska współistnieją ze sobą i wynikają ze zmian technologicznych oraz dostosowania do rosnącej konkurencji (Stankovic i in., 2013; Drobietz, Poth, 2017). Badania (Smite i in., 2010a; 2010b) wykazały, że $\mathrm{z}$ powodzeniem stosowano te podejścia $\mathrm{w}$ projektach z rozproszonymi geograficznie i społeczno-kulturowymi zespołami. Zdarza się niejednokrotnie, że ich metodyki wykorzystuje się nawet w tym samym projekcie, w różnych jego fazach, w zależności od potrzeb.

Problem badawczy przedstawiony w pracy dotyczy aktualnej identyfikacji czynników przesądzających o skutecznym zarządzaniu projektem usług IT, które uwzględniają polskie uwarunkowania (Bukłaha, Juchniewicz, 2019). Oprócz aspektu teoriopoznawczego, który jest ograniczony ze względu na wstępny charakter badań, przedstawione wyniki stanowią również podstawę do rozwinięcia sugestii dla praktyków zarządzania takimi projektami. Szczegółowym celem tego artykułu jest wstępna identyfikacja i interpretacja potencjalnych czynników sukcesu dla projektów związanych z usługami IT występujących zarówno w podejściach tradycyjnych, jak i zwinnych. Przeprowadzono badania o wstępnym charakterze $\mathrm{z}$ wykorzystaniem kwestionariusza ankietowego, a respondentami byli kierownicy projektów usług IT. Wyniki badań poddane zostały eksploracyjnej analizie czynnikowej, na podstawie której wyodrębniono i przeanalizowano czynniki, mogące mieć wpływ na powodzenie projektów usług IT.

\section{Przegląd literatury}

A naliza literatury związanej z pojęciem sukcesu projektu nie jest jednoznaczna. W tej pracy projekt rozumie się jako „tymczasowe przedsięwzięcie mające na celu stworzenie unikalnego produktu, usługi lub wyniku" (PMI, 2017). Skupiając się na określeniu pojęcia sukcesu w projektach IT, rozważyć należy podział na sukces projektu i sukces zarządzania projektem. Sukces projektu odnosi się do celów projektu, które są najbardziej odpowiednimi kryteriami sukcesu. A. de Wit (1988, s. 165) zdefiniował sukces projektu jako projekt, który „spełnia techniczną specyfikację wykonania i/lub misję do wykonania oraz jeśli istnieje wysoki poziom satysfakcji z wyniku projektu wśród kluczowych osób w organizacji macierzystej, kluczowych osób w zespole projektowym i kluczowych użytkowników lub klientów projektu”.

Natomiast sukces zarządzania projektem odnosi się do tradycyjnych miar wydajności, takich jak koszt, czas i jakość, które decydują o sukcesie zarządzania projektem (de Wit, 1988; Ika, 2009; Drury-Grogan, 2014). Miary te nazywane są także miarami obiektywnymi, których uzupełnieniem są miary subiektywne, odnoszące się do satysfakcji wszystkich interesariuszy projektu (Chan, Chan, 2004; Davis, 2014). Są to najczęściej zespoły projektowe, a w szczególności kierownicy projektu u odbiorcy oraz kierownicy projektu u dostawcy. Do 2015 roku badania w zakresie czynników mających wpływ na powodzenie projektów, przeprowadzane cyklicznie na dużą skalę przez Standish Group, jako nieliczne, nie uwzględniały miar subiektywnych. W późniejszych badaniach czynnik satysfakcji był już brany pod uwagę (Standish, 2015). Zmiana ta związana była $\mathrm{z}$ wynikami badań pokazujących, że sukces zarządzania projektem odnoszący się wyłącznie do zakładanych kosztów i czasu nie jest gwarancją całościowego sukcesu projektu (Skalik, Strzelczyk, 2013; Standish, 2015).

Przy określaniu elementów wpływających na sukces projektu wyróżnia się dodatkowo tak zwane krytyczne czynniki sukcesu (Rockart, 1979). Definiuje się je jako „ograniczoną liczbę obszarów, w których zadowalające 
wyniki zapewnią udaną konkurencję dla poszczególnych osób, działów lub organizacji. Krytyczne czynniki sukcesu to kilka kluczowych obszarów, w których wszystko musi pójść dobrze, aby biznes mógł się rozwijać i aby cele menedżera zostały osiągnięte" (Bullen, Rockart, 1981, s. 7).

$\mathrm{Na}$ potrzeby tego artykułu przyjęto, że elementami wpływającymi na sukces projektu są dane wejściowe do systemu zarządzania, które mogą bezpośrednio lub pośrednio prowadzić do powodzenia projektu (de Wit, 1988). Listę potencjalnych elementów wpływających na sukces projektu podają $\mathrm{w}$ swych pracach tacy badacze, jak przykładowo: P.W. Morris (1986), T. Cooke-Davies (2002), CERF (2004), T. Chow, D.-B. Cao (2008), C.F. Carroll (2013), Standish (2015). Korzystając między innymi z tych opracowań, przygotowano kwestionariusz na potrzeby przedstawianego badania.

\section{Metoda badawcza}

W badaniu wykorzystano kwestionariusz ankietowy przygotowany $\mathrm{w}$ formie elektronicznego arkusza kalkulacyjnego programu Microsoft Excel. Zakres i dobór pytań w kwestionariuszu uwzględnia zarówno podejścia tradycyjne, jak i zwinne. W obszarze metodyk zwinnych wykorzystano część pytań z badań na temat sukcesu projektów zwinnych w sektorze oprogramowania (Chow, Cao, 2008; Stankovic i in., 2013), które zostały dostosowane do obecnego badania czynników sukcesu w zakresie wszystkich usług IT, a nie tylko oprogramowania. Ze względu na podobne charakterystyki czynniki powodzenia i niepowodzenia projektów zostały skonsolidowane do 44 zmiennych (pytań).

Ankiety wypełnili kierownicy zakończonych projektów z sektora usług IT. Respondenci proszeni byli o odpowiedzi dotyczące ostatnio zakończonego przez nich projektu. Narzędzie badawcze składało się z trzech sekcji. Część pierwsza zawierała informacje dotyczące projektu oraz kierownika projektu. Sekcja druga obejmowała pytania o elementy potencjalne wpływające na sukces. Ostatni komponent obejmowal dodatkowe komentarze i informacje, które ankietowany mógł przedstawić w postaci swobodnej wypowiedzi. Kwestionariusz został poddany ocenie metodycznej przez 14 ekspertów merytorycznych w dziedzinie budowy kwestionariuszy i zarządzania projektami. Ze względu na spore trudności w swobodnym dostępie do dużej liczby ekspertów w tych dziedzinach, prosiliśmy o konsultacje znajomych badaczy i menedżerów, którzy posiadają wiedzę i doświadczenie w tym zakresie. Wśród nich znaleźli się psychologowie i socjologowie biegli w tworzeniu kwestionariuszy i analizie tego typu danych oraz naukowcy zajmujący się zarządzaniem projektami, kierownicy projektów informatycznych i szefowie działów zarządzania projektami. Weryfikacji poddano poprawność gramatyczną, stylistyczną, semantyczną, typów pytań, skal, szczegółowości, struktury oraz spójności logicznej. Przedstawione uwagi i sugestie zaangażowanych ekspertów miały realny wpływ na ostateczny kształt kwestinariusza, który został wykorzystany w prezentowanym badaniu.

Badanie było anonimowe i przeprowadzono je w 2019 roku na przełomie stycznia i lutego. W ciągu miesiąca zgromadzono piętnaście $\mathrm{w}$ pełni wypełnionych $\mathrm{w}$ formie papierowej lub elektronicznej ankiet. Ankietowani pytani byli o ocenę przedstawionych potencjalnych elementów wpływających na sukces projektu. Wykorzystano w tym celu 7-stopniową skalę Likerta: 1 - zdecydowanie się nie zgadzam, 2 - nie zgadzam się, 3 - trochę się nie zgadzam, 4 - ani się nie zgadzam, ani zgadzam, 5 - trochę się zgadzam, 6 - zgadzam się, 7 - zdecydowanie się zgadzam.

Wśród uczestników badania kierownicy projektów mężczyźni stanowili 73\%, a kobiety $27 \%$. Ankietowani posiadali duże doświadczenie w sektorze IT: do 6 lat - 20\%, powyżej 6 lat - 80\%, przy średniej ponad 13 lat. Ich doświadczenie jako kierowników projektu w sektorze IT to kolejno: do 6 lat - 40\%, powyżej 6 lat - 60\%, przy średniej 10 lat. Ankietowani wskazali trzy kategorie projektów, w których uczestniczyli: budowa nowego systemu lub usługi (53\%), rozszerzenie funkcjonalności istniejącego systemu lub usługi (27\%) oraz utrzymanie istniejącego systemu lub usługi (20\%). Badani uczestniczyli w projektach, które średnio trwały 15 miesięcy. Zdecydowana większość projektów (90\%) była zrealizowana dla klientów zewnętrznych, a zaledwie $10 \%$ dla odbiorców wewnętrznych.

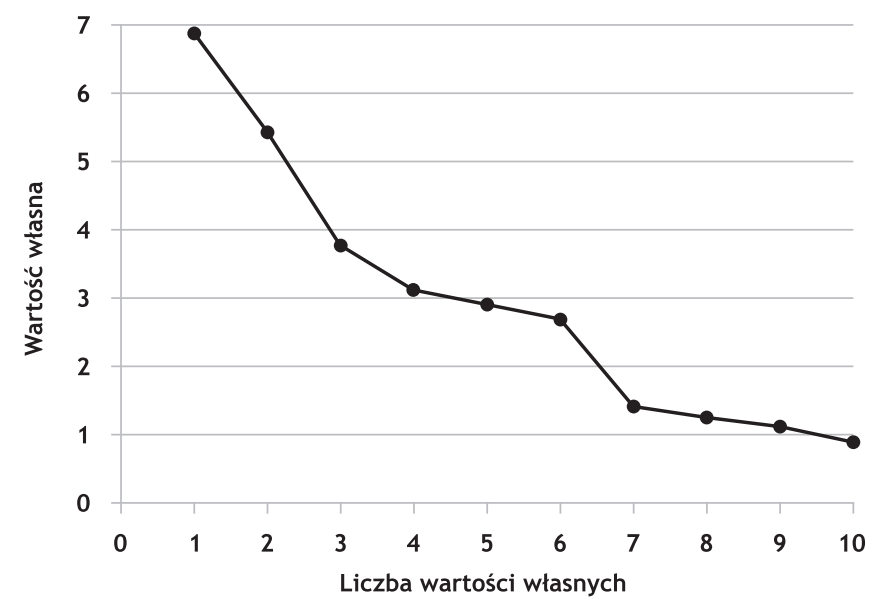

Rys. 1. Test osypiska

Źródto: opracowanie własne 
Tabela 1. Wartości własne składowych głównych poszczególnych czynników

\begin{tabular}{|c|c|c|c|c|}
\hline Czynnik & Wartość własna & $\begin{array}{c}\text { Procent całkowitej } \\
\text { wariancji }\end{array}$ & $\begin{array}{c}\text { Skumulowana } \\
\text { wartość własna }\end{array}$ & $\begin{array}{c}\text { Skumulowany } \\
\text { procent wariancji }\end{array}$ \\
\hline 1 & 6,9 & 22,2 & 6,9 & 22,2 \\
\hline 2 & 5,5 & 17,6 & 12,3 & 39,8 \\
\hline 3 & 3,8 & 12,2 & 16,1 & 52,0 \\
\hline 4 & 3,1 & 10,1 & 19,2 & 71,4 \\
\hline 5 & 2,9 & 9,4 & 22,1 & 80,1 \\
\hline
\end{tabular}

Źródło: opracowanie wtasne

Tabela 2. Czynnik 1 - Współpraca zespotów

\begin{tabular}{|c|l|l|c|}
\hline \multicolumn{2}{|c|}{ Zmienna } & Ladunek \\
\hline P06 & Rozmieszczenie zespołu & $\begin{array}{l}\text { Wszyscy członkowie zespołu pracowali w tym samym miejscu dla ułatwienia } \\
\text { komunikacji i swobodnego, stałego kontaktu. }\end{array}$ & - \\
\hline P13 & Relacje z klientem & Kierownictwo projektu miało dobre relacje z klientem. & + \\
\hline P29 & Zespoły interdyscyplinarne & Zespoły działały jako zespoły angażujące osoby z różnych dziedzin. & + \\
\hline P31 & Zarządzanie zmianą & $\begin{array}{l}\text { W projekcie wykorzystano proces zarządzania zmianą (rejestrowanie, planowanie, } \\
\text { i prumentowanie, testowanie, akceptowanie, ocena, autoryzacja, implementacja }\end{array}$ & + \\
\hline P37 & Harmonogram projektu & Harmonogób kontrolowany). & + \\
\hline P39 & Niezależne zespoły & W projekcie nie było wielu niezależnych zespołów współpracujących ze sobą. & - \\
\hline
\end{tabular}

Źródto: opracowanie własne

Tabela 3. Czynnik 2 - Zaangażowanie zespołu

\begin{tabular}{|c|l|l|c|}
\hline \multicolumn{2}{|l|}{ Zmienna } & Ladunek \\
\hline P05 & Metodyka zwinna w projekcie & W projekcie dopuszczono stosowanie metodyki zwinnej lub jej elementów. & - \\
\hline P08 & Kompetencje i wiedza & $\begin{array}{l}\text { Wybrani członkowie zespołu projektowego mieli wysokie kompetencje techniczne } \\
\text { i wiedzę specjalistyczną (rozwiązywanie problemów, merytoryka). }\end{array}$ & + \\
\hline P09 & Motywacja & $\begin{array}{l}\text { Członkowie zespołu projektowego mieli dużą motywację i byli zaangażowani } \\
\text { w realizację projektu w najlepszy możliwy sposób. }\end{array}$ & + \\
\hline P10 & Zwinne zasady & Kierownictwo projektu posiadało wiedzę w zakresie zwinnych zasad i procesów. & - \\
\hline P12 & Samoorganizacja & $\begin{array}{l}\text { Zespół pracował w sposób spójny i samozorganizowany, tj. polegał na autonomicznej } \\
\text { zdolności zespołu do rozwiązywania problemów i dostosowania się do zmieniających } \\
\text { się warunków. }\end{array}$ & + \\
\hline P18 & Komunikacja w zespole & W projekcie działały stałe kanały komunikacji pomiędzy członkami zespołu. & + \\
\hline P22 & Uprawnienia klienta & $\begin{array}{l}\text { Przedstawiciel klienta w projekcie miał pełne uprawnienia i wiedzę do podejmowania } \\
\text { pecyzji, takich jak zatwierdzanie, odrzucanie i ustalanie priorytetów wymagań } \\
\text { projektu i dokonywanie zmian. }\end{array}$ & + \\
\hline P33 & Dostarczone produkty & W projekcie dostarczano regularnie i szybko działające produkty / wyniki. \\
\hline P34 & Najważniejsze funkcje & $\begin{array}{l}\text { W projekcie w pierwszej kolejności realizowano najważniejsze funkcje z punktu } \\
\text { widzenia klienta. }\end{array}$ & + \\
\hline
\end{tabular}

Źródto: opracowanie własne 
Tabela 4. Czynnik 3 - Wsparcie procesu zarządzania i szkoleń

\begin{tabular}{|c|l|l|l|}
\hline \multicolumn{2}{|c|}{ Zmienna } & \multicolumn{2}{c|}{ Ladunek } \\
\hline P01 & Wsparcie kierownictwa & Projekt otrzymał silne wsparcie kierownictwa/zarządu & + \\
\hline P03 & Hierarchia & $\begin{array}{l}\text { W projekcie wykorzystywano hierarchiczną kulturę, która ma wyraźny podział } \\
\text { odpowiedzialności i uprawnień. }\end{array}$ \\
\hline P23 & Szkolenie & $\begin{array}{l}\text { Zespół projektowy miał zapewnione odpowiednie przeszkolenie, w tym w zakresie } \\
\text { dziedzinowym, procesów zwinnych i narzędzi. }\end{array}$ \\
\hline P25 & Efektywność & $\begin{array}{l}\text { W celu uzyskania większej efektywności ograniczano liczbę zadań będących w toku } \\
\text { i likwidowano wąskie gardła blokujące sprawność wykonywania prac. }\end{array}$ \\
\hline P32 & Dokumentacja zwinna & $\begin{array}{l}\text { W ramach projektu utrzymywano odpowiedni poziom szczegółowości dokumentacji. } \\
\text { Nie koncentrowała się ona zbytnio na tworzeniu nadmiernie skomplikowanych } \\
\text { i drobiazgowych wpisów. }\end{array}$ \\
+
\end{tabular}

Źródło: opracowanie własne

Tabela 5. Czynnik 4 - Zwinne zarządzanie planowaniem

\begin{tabular}{|c|l|l|c|}
\hline \multicolumn{2}{|c|}{ Zmienna } & \multicolumn{1}{|c|}{ Ladunek } \\
\hline P15 & Wymagania & $\begin{array}{l}\text { W projekcie zastosowano okrélenie początkowych wymagán na bardzo wysokim } \\
\text { poziomie, pozostawiając dużo miejsca na interpretację i adaptację w trakcie jego } \\
\text { trwania. }\end{array}$ & + \\
\hline P16 & Plany & $\begin{array}{l}\text { W projekcie zastosowano plany, które zasadniczo nie były szczegółowo } \\
\text { dokumentowane, a odchylenia i zmiany były łatwo akceptowane i włączane do planu } \\
\text { projektu. }\end{array}$ & + \\
\hline P24 & Szkolenie z metodyki zwinnej & Kierownik projektu przeszedł szkolenie z metodyki zwinnej. & + \\
\hline
\end{tabular}

Źródło: opracowanie własne

\section{Wyniki badań}

\section{Dobór zmiennych i identyfikacja czynników}

W celu identyfikacji czynników wpływających na sukces projektów w obszarze usług IT przeprowadzono eksploracyjną analizę czynnikową uwzględniającą wszystkie 44 zmienne wynikające z przeglądu literatury.

Analiza uzyskanych rezultatów miała charakter krokowy. W kolejnych etapach eliminowano zmienne, które nie korelowały z żadnym czynnikiem albo wysoko korelowały z dwoma lub więcej czynnikami. W pierwszej kolejności usuwano zmienne, których wszystkie ładunki czynnikowe były mniejsze lub równe 0,5. Następnie eliminowano zmienne, które wysoko korelowały z większą liczbą czynników. Zmienne były wyłączane $\mathrm{z}$ modelu pojedynczo, a po każdej takiej czynności powtarzano proces eksploracyjnej analizy czynnikowej. Łącznie przeprowadzono jedenaście iteracji. W celu określenia liczby czynników uwzględnianych w finalnej wersji analizy czynnikowej stosowano klasyczny test osypiska. Graficzną reprezentację tego testu dla finalnej iteracji prezentuje rysunek 1.

Analizując przedstawiony wykres, nietrudno zauważyć, że po szóstej wartości własnej, dodawanie kolejnych przynosi niewielkie korzyści w kontekście wyjaśnianej wariancji. Szczegółowa analiza danych $\mathrm{z}$ tabeli 1 pokazuje dodatkowo, że uwzględnienie wyłącznie pierwszych sześciu czynników umożliwia wyjaśnienie ponad 80\% zmienności w całym badaniu.
W związku z wynikami uzyskanymi w trakcie eliminacji nieadekwatnych zmiennych i powyższym testem osypiska przyjęto finalnie strukturę analizy czynnikowej składającą się z sześciu czynników (F) i 31 zmiennych (P). W kolejnej części artykułu zmienne, które zostały włączone do modelu, scharakteryzowano i pogrupowano względem wyróżnionych czynników.

\section{Interpretacja czynników}

Sześć zasadniczych czynników, które zostały wyodrębnione w poprzedniej sekcji, wymaga przedstawienia ich interpretacji. Zaproponowano następujące nazwy dla poszczególnych grup zmiennych:

1) współpraca zespołów (F1),

2) zaangażowanie zespołu (F2),

3) wsparcie procesu zarządzania i szkoleń (F3),

4) zwinne zarządzanie planowaniem (F4),

5) organizacja środowiska pracy (F5),

6) elastyczność (F6).

Poniżej szczegółowo przedstawiono zmienne składowe dla zidentyfikowanych czynników wraz z ładunkiem korelacji $(+/-)$.

Pierwszy czynnik odnosi się do współpracy zespołów i dotyczy lokalizacji wykonywania pracy, zarządzania wirtualnego czy składu zespołów interdyscyplinarnych, np. administratorzy Unix, Linux, baz danych, pamięci masowej, inżynierowie średniego szczebla, kierownicy projektów itd. Zmienne związane $\mathrm{z}$ rozmieszczeniem 
Tabela 6. Czynnik 5 - Organizacja środowiska pracy

\begin{tabular}{|c|l|l|l|}
\hline \multicolumn{2}{|c|}{ Zmienna } \\
\hline P07 & Zwinny obiekt & $\begin{array}{l}\text { Zespół projektowy pracował w takim środowisku pracy, jak: otwarta przestrzeń, } \\
\text { wspólna przestrzeń, obszerne miejsca na ścianie na ogłoszenia, informacje itp. }\end{array}$ \\
\hline P19 & $\begin{array}{l}\text { Komunikacja } \\
\text { zespół-kierownictwo }\end{array}$ & W projekcie działały stałe kanały komunikacji pomiędzy zespołem a kierownictwem. \\
\hline P30 & Wyniki & $\begin{array}{l}\text { W projekcie w celu zwiększenia przepustowości i przepływu skupiano się na } \\
\text { dostarczonych wynikach pracy zamiast na tym, jak wykorzystywani byli członkowie } \\
\text { zespołu. }\end{array}$ \\
\hline P42 & Role i odpowiedzialność & Role i odpowiedzialność w projekcie zostały określone. \\
\hline
\end{tabular}

Źródło: opracowanie własne

Tabela 7. Czynnik 6 - Elastyczność

\begin{tabular}{|c|l|l|}
\hline \multicolumn{2}{|c|}{ Zmienna } \\
\hline P02 & Współpraca & $\begin{array}{l}\text { W projekcie wykorzystano kulturę współpracy, która wspiera zespoły doraźne, } \\
\text { kierowane potrzebami danej pracy. }\end{array}$ \\
\hline P04 & Płynna komunikacja & $\begin{array}{l}\text { W projekcie przywiązywano dużą wagę do płynnego, bezpośredniego stylu } \\
\text { komunikacji. }\end{array}$ \\
\hline P11 & Elastyczność, kreatywność & $\begin{array}{l}\text { Projekt zachęcał do kreatywnego, elastycznego środowiska pracy, ciągłego uczenia się } \\
\text { i adaptacji, wykorzystując wzajemne interakcje między różnymi częściami projektu. }\end{array}$ \\
\hline P43 & Współinteresariusze & Analizowano wpływ współinteresariuszy na projekt. \\
\hline
\end{tabular}

Źródło: opracowanie własne

zespołu oraz brakiem niezależności zespołów ujemnie korelowały z tym czynnikiem. Dodani wpływ miały natomiast: relacje $\mathrm{z}$ klientem, zespoły interdyscyplinarne oraz zarządzanie zmianą i zmiennym harmonogramem projektu. Informacje te podano w tabeli 2 .

Zaangażowanie zespołu wyrażane może być poprzez wysoką motywację, odpowiedzialność, wysokie kompetencje i umiejętności, wysoką jakość i czasową realizację prac, samoorganizację, samodzielność i komunikację. Tutaj, zmienne odnoszące się do metodyki zwinnej i zwinnych zasad kierownictwa projektem miały ujemną korelację, pozostałe korelowały dodatnio. Szczegóły dla drugiego czynnika znajdują się w tabeli 3 .

W tabeli 4 zestawiono zmienne określające trzeci czynnik odnoszący się do wsparcia procesu zarządzania i zapewnienia odpowiednich szkoleń. W tym przypadku wszystkie zmienne pozytywnie korelowały z wyróżnionym czynnikiem.

Zmienne określające czwarty czynnik umieszczono $\mathrm{w}$ tabeli 5. Jest on związany ze zwinnym podejściem do zarządzania planowaniem $\mathrm{w}$ projekcie i dotyczy takich kwestii, jak początkowe wymagania i związane z nimi plany oraz szkolenia ze zwinnych metod. Również tutaj dla wszystkich zmiennych ładunek korelacji był pozytywny.

Czynnik odnoszący się do organizacji środowiska pracy uwzględnia warunki przestrzenne, w których projekt jest wykonywany i zarządzany, sprawne funkcjonowanie komunikacji między interesariuszami $\mathrm{w}$ projekcie oraz sposób rozdziału pracy i odpowiedzialności. Ładunki korelacji dla każdej zmiennej w ramach tego czynnika były dodatnie. Dokładne dane zawarto w tabeli 6.

Elastyczność rozumiana jest poprzez kreatywność zespołu, sprawną komunikację i płynność w działaniu ze wszystkimi interesariuszami w projekcie. Wszystkie zmienne charakteryzujące ten czynnik miały pozytywny ładunek. Precyzyjne informacje zawiera tabela 7.

Ostatecznie uzyskana struktura wraz z wyestymowanymi ładunkami czynnikowymi została przedstawiona w tabeli 8, gdzie pogrubiono korelacje, których wartość bezwzględna jest większa od 0,5.

\section{Dyskusja wyników}

M rezultacie analiz wyników przeprowadzonych badań i korzystając z testu osypiska, wyodrębniono sześć czynników sukcesu realizacji projektów usług IT. Czynniki te definiowane są przez 31 zmiennych. Uzyskane wyniki różnią się zarówno jakościowo, jak i ilościowo od rezultatów podobnych badań prowadzonych na świecie. Przykładowo, T. Chow i D.-B. Ciao (2008) w swojej pracy wyodrębnili aż 12 czynników charakteryzowanych przez podobną do naszej liczbę zmiennych (39 pytań). W badaniach będących kontynuacją pracy T. Chow i D.-B. Ciao (2008), D. Stankovic i inni (2013), stosując ten sam kwestionariusz co wspomniani wyżej autorzy, ale w innym środowisku, wyodrębnili siedem czynników. 
Tabela 8. Finalne tadunki czynnikowe dla uwzględnionych zmiennych

\begin{tabular}{|c|c|c|c|c|c|c|}
\hline Zmienna & $\begin{array}{c}\text { Współpraca } \\
\text { zespołów (F1) }\end{array}$ & $\begin{array}{c}\text { Zaangażowanie } \\
\text { zespołu (F2) }\end{array}$ & $\begin{array}{c}\text { Wsparcie } \\
\text { zarządzania } \\
\text { i szkoleń (F3) }\end{array}$ & $\begin{array}{c}\text { Zwinne } \\
\text { zarządzanie } \\
\text { planowania } \\
\text { (F4) }\end{array}$ & $\begin{array}{c}\text { Organizacja } \\
\text { środowiska } \\
\text { pracy (F5) }\end{array}$ & $\begin{array}{c}\text { Elastyczność } \\
(\mathrm{F} 6)\end{array}$ \\
\hline P01 & $-0,159$ & 0,018 & 0,718 & 0,378 & $-0,296$ & 0,233 \\
\hline P02 & $-0,008$ & 0,191 & $-0,021$ & 0,117 & $-0,168$ & 0,820 \\
\hline P03 & $-0,043$ & 0,102 & 0,771 & $-0,200$ & 0,310 & $-0,102$ \\
\hline P04 & 0,280 & $-0,057$ & 0,114 & 0,362 & 0,123 & 0,741 \\
\hline P05 & $-0,051$ & $-0,591$ & 0,157 & $-0,338$ & 0,414 & 0,075 \\
\hline P06 & $-0,639$ & $-0,110$ & $-0,340$ & 0,184 & 0,277 & 0,312 \\
\hline P07 & $-0,078$ & 0,157 & 0,050 & 0,228 & 0,861 & $-0,130$ \\
\hline P08 & $-0,080$ & 0,867 & $-0,056$ & $-0,333$ & 0,167 & 0,127 \\
\hline P09 & 0,001 & 0,739 & 0,184 & $-0,402$ & $-0,083$ & 0,304 \\
\hline P10 & $-0,175$ & $-0,526$ & 0,208 & 0,142 & 0,385 & 0,166 \\
\hline P11 & 0,180 & 0,070 & 0,378 & 0,109 & 0,105 & 0,799 \\
\hline P12 & 0,030 & 0,539 & 0,363 & $-0,455$ & 0,436 & 0,251 \\
\hline P13 & 0,711 & $-0,126$ & 0,324 & 0,260 & 0,220 & 0,382 \\
\hline P15 & $-0,028$ & 0,009 & 0,013 & 0,821 & 0,083 & 0,252 \\
\hline P16 & 0,324 & $-0,089$ & 0,051 & 0,851 & 0,104 & 0,183 \\
\hline P18 & 0,061 & 0,794 & $-0,189$ & $-0,102$ & 0,377 & $-0,073$ \\
\hline P19 & 0,416 & 0,137 & $-0,073$ & $-0,062$ & 0,826 & 0,160 \\
\hline P22 & $-0,023$ & 0,707 & 0,432 & 0,338 & 0,021 & $-0,218$ \\
\hline P23 & 0,102 & $-0,205$ & 0,836 & 0,099 & 0,172 & 0,214 \\
\hline P24 & 0,409 & 0,044 & 0,242 & 0,585 & 0,173 & $-0,141$ \\
\hline P25 & 0,408 & 0,113 & 0,769 & 0,305 & $-0,198$ & 0,169 \\
\hline P29 & 0,892 & $-0,004$ & $-0,071$ & $-0,005$ & $-0,001$ & 0,296 \\
\hline P30 & $-0,077$ & 0,358 & 0,137 & 0,219 & 0,799 & $-0,029$ \\
\hline P31 & 0,836 & 0,120 & 0,126 & 0,230 & 0,265 & 0,067 \\
\hline P32 & 0,060 & 0,111 & 0,763 & $-0,319$ & 0,216 & $-0,098$ \\
\hline P33 & 0,081 & 0,849 & 0,020 & 0,058 & 0,234 & 0,003 \\
\hline P34 & $-0,203$ & 0,804 & 0,049 & 0,383 & 0,155 & 0,241 \\
\hline P37 & 0,646 & 0,013 & $-0,463$ & 0,312 & $-0,364$ & $-0,237$ \\
\hline P39 & $-0,823$ & 0,219 & $-0,051$ & 0,032 & $-0,050$ & $-0,091$ \\
\hline P42 & 0,101 & 0,114 & 0,267 & $-0,228$ & 0,656 & 0,135 \\
\hline P43 & 0,161 & 0,138 & $-0,054$ & $-0,130$ & 0,046 & 0,758 \\
\hline
\end{tabular}


Liczba ta jest zdecydowanie bliższa rezultatom uzyskanym przez autorów niniejszego artykułu. Z kolei A. Aldahmash i inni (2017) zidentyfikowali tylko dwa czynniki, wykorzystując zaledwie osiem zmiennych.

Wyróżniony przez autorów opracowania czynnik zaangażowanie zespołu jest spójny z czynnikami zdolności zespołu oraz strategia dostarczania (przejawiająca się dostarczaniem produktów na czas i realizująca w pierwszej kolejności najważniejsze funkcje) zidentyfikowanymi przez T. Chow i D.-B. Ciao (2008). Analogicznie, nasz czynnik wsparcia procesu zarządzania i szkoleń można odnieść do czynnika wsparcie i zaangażowanie kierownictwa wyodrębnionego przez tych autorów. Podobnie jest z czynnikami zwinne zarządzanie planowania i zwinne zarządzanie projektem. W odniesieniu do naszego czynnika elastyczność, zbieżność można zauważyć w składowych czynnika środowiska organizacji dotyczącego współpracy i płynnej komunikacji. W relacji do badań A. Aldahmash i innych (2017) czynnik ludzki i organizacyjny wykazał spójność ze składowymi czynników zaangażowanie zespołu oraz wsparcie procesu zarządzania i szkoleń. D. Stankovic i inni (2013) w pierwszym czynniku zidentyfikowali aż 20 składowych. Zbieżność można zauważyć dla składowych pięciu czynników: zaangażowanie zespołu, współpraca zespołów, wsparcie procesu zarządzania i szkoleń, zwinne zarządzanie planowania oraz elastyczność.

Powyższa analiza wyraźnie pokazuje dość spore różnice w rezultatach uzyskanych przez różnych badaczy. Rozbieżności dotyczą zarówno liczby czynników, jak i liczby i zakresu zmiennych te czynniki definiujących. Takie niezgodności mogą wynikać $\mathrm{z}$ różnorodności projektów, w których uczestniczyli ankietowani kierownicy. Również nie bez znaczenia jest wielkość i charakterystyka próby badawczej. Czynniki, takie jak doświadczenie, wiek czy znajomość i biegłość w korzystaniu z różnych metodyk zarządzania projektami, mogły mieć znaczący wpływ na uzyskiwane rezultaty. Wpływ przypuszczalnie miało także otoczenie funkcjonowania kierowników projektów, na przykład istniejąca kultura organizacyjna czy wewnętrzne procedury.

Oprócz kontrybucji teoretycznej, która $\mathrm{z}$ racji pilotażowego charakteru przedstawionych badań jest ograniczona, przedstawione wyniki mogą stanowić cenne źródło informacji dla praktyków zarządzania. Zidentyfikowano i scharakteryzowano tutaj obszary i czynniki, które mogą w znaczącym stopniu przyczynić się do zwiększenia szans na skuteczną i efektywną realizację projektów z branży usług IT. Do najciekawszych i nieoczywistych rezultatów można zaliczyć negatywną korelację zmiennych P05 (Metodyka zwinna w projekcie) i P10 (Zwinne zasady) z czynnikiem Zaangażowanie zespołu. Natomiast w pozostałych przypadkach zmienne kojarzone ze zwinnym podejściem posiadały dodatnie ładunki czynnikowe. Uzyskane rezultaty jednoznacznie pokazują na konieczność jednoczesnego stosowania zarówno klasycznych, jak i zwinnych metod zarządzania na każdym etapie realizacji. Wiedza i doświadczenie zarządzajacego projektem oraz dostępność i możliwość wykorzystania najlepszych praktyk w organizacji są tutaj kluczowe. Dlatego każdorazowo, przystępując do przedsięwzięcia, należy czerpać $\mathrm{z}$ wielu źródeł (np. wiedzy kierownika projektu czy repozytorium projektów wraz $\mathrm{z}$ analizą interesariuszy oraz procesów biznesowych stosowanych w organizacji), wybierając te elementy, które w największym stopniu zwiększą prawdopodobieństwo osiągnięcia końcowego sukcesu.

\section{Podsumowanie}

$\mathbf{P}$

rzeprowadzone badania i wyniki analizy czynnikowej pozwoliły na wyodrębnienie sześciu czynników: 1) współpraca zespołów, 2) zaangażowanie zespołu, 3) wsparcie procesu zarządzania i szkoleń, 4) zwinne zarządzanie planowania, 5) organizacja środowiska pracy oraz 6) elastyczność. Przedstawione czynniki stanowią potwierdzenie badań, w których wskazywano na przenikanie stosowania metodyk zarządzania tradycyjnych i zwinnych. Na sukces projektu składa się wiele elementów. Z jednej strony współpraca, elastyczność i zaangażowanie zespołów, które wykorzystują zwinne metodyki działań, a z drugiej wsparcie kierownictwa procesu zarządzania i odpowiedniej organizacji pracy pokazują, że łączenie różnych podejść w zarządzaniu projektem jest skutecznym rozwiązaniem na drodze do jego sukcesu.

Niewątpliwie sporym ograniczeniem przedstawionych badań jest stosunkowo mało liczna próba badawcza, która wynika głównie $\mathrm{z}$ bardzo ograniczonego dostępu do wysoko wykwalifikowanych kierowników projektów. Dodatkowo, w branży IT obserwuje się postępującą hermetyzację dotyczącą prowadzenia niezależnych badań naukowych i udostępniania jakichkolwiek danych podmiotom akademickim w celu ich publikacji. Postępowanie takie jest $\mathrm{z}$ jednej strony zrozumiałe $\mathrm{w}$ kontekście istniejącej konkurencji, jednak $\mathrm{z}$ drugiej strony znacznie utrudnia przygotowanie i przeprowadzenie badań zakrojonych na dużą skalę.

Pomimo wspomnianych ograniczeń, uzyskane wyniki wydają się interesujące i obiecujące. Zidentyfikowana za pomocą eksploracyjnej analizy czynnikowej struktura czynników sukcesu zarządzania projektami usług IT z pewnością będzie stanowić ważny i znaczący punkt wyjścia dla dalszych, zakrojonych na większą skalę badań w tym obszarze.

\section{mgr inż. Szymon Zaleski \\ Politechnika Wrocławska \\ Wydział Informatyki i Zarządzania \\ ORCID: 0000-0002-8131-1227 \\ e-mail: szymon.zaleski@pwr.edu.pl}

\author{
dr hab. inż. Rafał Michalski, prof. uczelni \\ Politechnika Wrocławska \\ Wydział Informatyki i Zarządzania \\ ORCID: 0000-0002-0807-1925 \\ e-mail: rafal.michalski@pwr.edu.pl
}




\section{Bibliografia}

[1] Aldahmash A., Gravell A., Howard Y. (2017), Using Factor Analysis to Study the Critical Success Factors of Agile Software Development, „Journal of Software”, Vol. 12, No. 12, pp. 957-963.

[2] Bukłaha E., Juchniewicz M. (2019), Kluczowe wyzwania $i$ bariery oraz trendy $w$ zarzadzaniu projektami $z$ punktu widzenia projektów realizowanych w Polsce, „Przegląd Organizacji”, Nr 3, s. 14-20.

[3] Bullen C.V., Rockart J.F. (1981), A Primer on Critical Success Factors, Working Paper No. 69, CISR, Cambridge.

[4] Carroll C.F. (2013), IT Success and Failure: The Standish Group CHAOS Report Success Factors, http://www.cafe-encounter.net/p1183/it-success-and-failure-the-chaos-repor$\mathrm{t}$-factors, access date: 15.01.2020.

[5] CERF (2004), Independent Research Assessment of Project Management Factors Affecting Department of Energy Project Success: Final Report, Office of Engineering and Construction Management, U.S. Department of Energy.

[6] Chan A.P.C., Chan A.P.L. (2004), Key Performance Indicators for Measuring Construction Success, „Benchmarking: An International Journal", Vol. 11, No. 2, pp. 203-221.

[7] Chow T., Cao D.-B. (2008), A Survey Study for Critical Success Factors in Agile Software Projects, „Journal of Systems and Software", Vol. 81, pp. 961-971.

[8] Cooke-Davies T. (2002), The „Real” Success Factors on Projects, „International Journal of Project Management”, Vol. 20, No. 3, pp. 185-190.

[9] Davis K. (2014), Different Stakeholder Groups and their Perceptions of Project Success, „International Journal of Project Management", Vol. 32, No. 2, pp. 189-201.

[10] de Wit A. (1988), Measurement of Project Success, „International Journal of Project Management", Vol. 6, No. 3, pp. 64-170.

[11] Drobietz M., Poth A. (2017), A New Approach: Not Agile vs. Traditional QM but Applying the Best of Both, [in:] J. Stolfa, S. Stolfa, R. O'Connor, R. Messnarz (eds.), Systems, Software and Services Process Improvement, Springer, Cham, pp. 486-494.

[12] Drury-Grogan M.L. (2014), Performance on Agile Teams: Relating Iteration Objectives and Critical Decisions to Project Management Success Factors, „Information and Software Technology", Vol. 56, No. 5, pp. 506-515.

[13] Ika L.A. (2009), Project Success as a Topic in Project Management Journals, „Project Management Journal”, Vol. 40, No. 4, pp. 6-19.

[14] Konieczna I. (2019), Popularyzacja badań w zakresie zarządzania projektami - Wyniki badań bibliometrycznych, „Przegląd Organizacji”, Nr 3, s. 27-32.

[15] Morris P.W. (1986), Project Management: A View from Oxford, „International Journal of Construction Management and Technology", Vol. 1, pp. 36-52.

[16] Project Management Institute (2017), A Guide to the Project Management Body of Knowledge. PMBOK Guide. Sixth Edition, Newtown Square, PA.

[17] Rockart J.F. (1979), Chief Executives Define their own Data Needs, „Harvard Business Review”, Vol. 57, No. 2, pp. 81-93.
[18] Skalik J., Strzelczyk A. (2013), Kluczowe czynniki sukcesu $w$ zarzadzaniu projektami informatycznymi, „Zarządzanie i Finanse. Prace i Materiały Wydziału Zarządzania Uniwersytetu Gdańskiego", Nr 4, s. 265-276.

[19] Smite D., Moe N.B., Agerfalk P.J. (2010a), Fundamentals of Agile Distributed Software Development, [in:] D. Smite, N.B. Moe, P.J. Agerfalk (eds.), Agility Across Time and Space, Springer-Verlag, Berlin, Heidelberg, pp. 3-7.

[20] Smite D., Moe N.B., Agerfalk P.J. (2010b), Agility Across Time and Space: Summing Up and Planning for the Future, [in:] D. Smite, N.B. Moe, P.J. Agerfalk (eds.), Agility Across Time and Space, Springer-Verlag, Berlin, Heidelberg, pp. 333-337.

[21] Standish Group International, Inc. (2015), Chaos Report 2015, https://www.standishgroup.com, access date: 23.02.2020.

[22] Stankovic D., Nikolic D., Djordjevic M., Cao D.-B. (2013), A Survey Study of Critical Success Factors in Agile Software Projects in Former Yugoslavia IT Companies, „Journal of Systems and Software", Vol. 86, No. 6, pp. 1663-1678.

[23] Szpitter A. (2012), Innowacyjne podejścia do zarządzania projektami, „Przegląd Organizacji”, Nr 1, s. 10-13.

[24] Varajão J., Magalhães L., Freitas L., Ribeiro P., Ramos J. (2018), Implementing Success Management in an IT Project, „Procedia Computer Science”, Vol. 138, pp. 891-898.

\section{Success Factors of Managing IT Services Projects}

\section{Summary}

In the world of rapid and constant changes, the development of information technology (IT) is one of the main elements influencing the effectiveness and efficiency of enterprises. Despite substantial expenditure of time, money and commitment to project management in this area, they are still quite often unsuccessful. These failures result in delays, changes in the initial assumptions or complete resignation from their implementation. Among many different techniques and methods available, approaches where traditional and agile environments coexist are gaining in popularity. The purpose of this article is to identify and interpret potential IT service project success factors in both traditional and agile contexts. Based on the existing literature, a list of potential critical success factors of IT services projects was identified and compiled. The conducted survey was based on a survey questionnaire and its respondents were IT project managers within IT service projects. The exploratory factor analysis has been used to distinguish six factors that have the biggest impact on projects, i.e., collaboration among teams, team's engagement, training and management process support, agile planning management, work environment organization, flexibility. The results of the factor analysis have been compared with analogous studies carried out by researchers from around the world. The research has shown that both traditional and agile management methodologies are important for the successful project management.

\section{Keywords}

project management, IT services projects, project success factors 